\title{
Uměle vytvořený srovnávací materiál pro účely písmoznaleckého zkoumání v kontextu s problematikou předložení padělaného či pozměněného di̊kazního prostředku Artificially Created Comparative Material for the Purposes of Peer Review in the Context of the Presentation of Falsified or Altered Evidence
}

\begin{abstract}
Abstrakt
Cílem příspěvku je formou kazuistiky a navazujícím právním pohledem seznámit čtenáře s aktuální problematikou z písmoznalecké praxe. V procesu dokazování je písmoznalecké zkoumání stěžejním nástrojem pro objasnění pravosti či nepravosti sporného podpisu anebo identifikace pisatele textu na nejrůznějších dokumentech. Skutečnost, že srovnávací materiál hraje při zkoumání podstatnou roli, si často uvědomují samotní účastníci soudních řízení i jejich právní zástupci. Snaha negativně ovlivnit anebo zpochybnit autentičnost tohoto materiálu je ze strany účastníků soudního řízení stále četnější. Tato snaha je mnohdy dovršena vytvořením umělého srovnávacího materiálu, který je jednou ze stran znalci předkládán s cílem, aby dospěl - pro daného účastníka soudního řízení - $\mathrm{k}$ žádoucímu závěru zkoumání. $K$ tomu, aby předložení či padělání předloženého důkazního prostředku bylo považováno za jednání trestné, bude se muset jednat o věcný nebo listinný důkazní prostředek, který bude mít současně tzv. „podstatný význam pro rozhodnutí" a bude použit v zákonem předpokládaném úmyslu.
\end{abstract}

\section{Klíčová slova}

písmoznalectví, sporný materiál, srovnávací materiál, znalecký posudek, umělý srovnávací materiál, dokazování, trestní řízení, trestný čin maření spravedlnosti, padělaný důkazní prostředek, pozměněný důkazní prostředek

\section{Abstract}

The objective of this paper is to inform readers by casuistry and legal point of view about topical issues of the forensic handwriting examination. The forensic handwriting examination is an essential tool in order to clarify authenticity or inauthenticity of the

1 Mgr. Helena Hornychová, znalec v oborech kriminalistika a písmoznalectví a místopředsedkyně Československé společnosti pro písmoznalectví, K Vořechu 1510, 29501 Mnichovo Hradiště, e-mail: HelenaHornychova@seznam.cz

2 JUDr. Markéta Brunová, Ph.D., LL.M., advokátka a vedoucí Katedry veřejného a evropského práva na VŠFS 
disputed sign or to identificate the writer of the diversified documents in the proceedings. The fact, that the comparative material has significant role in the examination, is often known to parties to the proceedings and to their legal counsellors.

The effort of parties to proceedings to negatively affect or to impeach the authenticity of the examined material is constantly increasing. This effort is often accomplished by manufacturing of the artificial comparative material, which is submitted to expert by one of the parties to proceedings with the aim to affect the results of the forensic handwriting examination to their advantage.

In order to consider submission or falsification of provided evidence as a criminal conduct, the provided evidence should be a material or a documentary evidence which also should have so called "significant reverence for a verdict" and would be used according to law presumed intentions.

\section{Key words}

forensic handwriting examination, disputed material, comparative material, expert report, artificial comparative material, proving, criminal proceedings, crime of obstructing of justice, counterfeit evidence, altered evidence

DOI

http://dx.doi.org/10.37355/fvpk-2020/1-05

\section{Úvod}

Průběh dokazování znaleckým posudkem z oboru písmoznalectví se u soudních jednání v posledních letech přesouvá od stvrzení závěru stanoveného znalcem do roviny obhajování použitého srovnávacího materiálu. V procesu dokazování je písmoznalecké zkoumání stěžejním nástrojem pro objasnění pravosti či nepravosti sporného podpisu anebo identifikace pisatele textu na nejrůznějších dokumentech, at' už se jedná o směnky, závěti, smlouvy aj. Skutečnost, že srovnávací materiál hraje podstatnou roli, si uvědomují samotní účastníci ř́zení i jejich právní zástupci. Snaha negativně ovlivnit srovnávací materiál anebo zpochybnit jeho autentičnost je pro to ze strany účastníků soudních řízení stále častější. Tato snaha je mnohdy dovršena uměle vytvořeným srovnávacím materiálem, který je jednou ze stran předkládán za účelem, aby znalec dospěl - pro daného účastníka soudního řízení - k žádoucímu závěru zkoumání.

\section{Písmoznalecké zkoumání}

Faktorů, které ovlivňují průběh písmoznaleckého zkoumání, je nemalá škála. Srovnávací materiál použitý k písmoznalecké komparaci je však pro zkoumání zásadní. ${ }^{3}$ Zatímco rozsah,

3 Výjimku tvoří např. případy, kdy je ke zkoumání předložena kopie sporného materiálu, a přitom je reálná 
kvalituazpracovatelnostsporného materiáluzpravidlanelzeovlivnit, usrovnávacího materiálu je tomu jinak. Obecně Ize uvést, že zajištění kvalitního, dostatečně rozsáhlého a časově adekvátního srovnávacího materiálu, který pochází z neutrálního a nezpochybnitelného zdroje, ideálně však z více různých zdrojů, je pro účely písmoznaleckého zkoumání stěžejní, má zásadní vliv na průběh zkoumání a přesnost stanoveného závěru. Předložení dostatečného množství srovnávacích listin z více zdrojů umožňuje znalci vyhodnotit jejich spolehlivost, protože případná selekce anebo kontaminace (at̉ už úmyslná či neúmyslná) srovnávacího materiálu není žádoucí, nebot’ by mohla (i když ne nutně) mít negativní důsledek na stanovení závěru. Osvědčeným srovnávacím materiálem, který je všeobecně považován za neutrální, nezpochybnitelný a autentický, jsou zejména úřední žádosti a dokumenty ze státní správy (např. žádosti o vydání osobních dokladů).

Některé soudy, zejména v civilních rízeních, nesprávně delegují povinnost na zajištění srovnávacího materiálu na znalce anebo považují za konečné řešení uložení jednotlivým účastníkům řízení povinnost poskytnout znalci součinnost. Je však nutno zdůraznit, že vedle součinnosti jednotlivých účastníků to je zejména spolupráce soudu, která je pro vytváření optimálních podmínek pro písmoznalecké zkoumání podstatná. Znalec nedisponuje pravomocemi k tomu, aby si neutrální a spolehlivý srovnávací materiál ze státní správy obstaral sám.

S neposkytnutím součinnosti ze strany jednotlivých účastníků řízení, někdy i ze strany samotného soudu, selekcí či kontaminací srovnávacího materiálu se setkáváme v písmoznalecké praxi poměrně často. Závažnější a v praxi se rozšiřující fenomén spočívá v podvržení uměle vytvořeného srovnávacího materiálu, který vzniká pro potřebu konkrétního písmoznaleckého zkoumání. Znalci je předkládán s úmyslem a cílem, aby jej použil ke zkoumání, a proto na první pohled mnohdy pưsobí takový materiál velmi věrohodně. Jak se problematika této agresivní formy úmyslné kontaminace srovnávacího materiálu odráží do praxe, vám přiblížím formou kazuistiky.

V rámci civilního soudního řízení bylo úkolem ověřit pravost několika podpisů na jméno zemřelé osoby. Nejednalo by se o nijak zvlášt mimořádný případ, kdyby soubor srovnávacích podpisů předložený žalovanou nevykazoval znaky uměle vytvořeného materiálu.

Ke zkoumání se podařilo zajistit dostatečně bohatý, kvalitní a časově adekvátní srovnávací materiál, který byl předložen účastníky řízení i soudem. Soud zajistil pravé podpisy dotyčné osoby z neutrálního zdroje veřejné správy, na úředních dokumentech, které bylo možno využít jako výchozí a spolehlivý autentický materiál (obr. č. 2). Po celkovém vyhodnocení srovnávacího materiálu bylo zjištěno, že ukázky vlastnoručních podpisů pisatele tvoří relativně stabilní skupinu, které se však výrazně vymykaly jak sporné podpisy (obr. č. 1), tak ukázky podpisů předložené žalovanou (obr. č. 3). Stejně jako v prípadě sporných podpisů se jednalo o napodobeniny vyhotovené tzv. z volné ruky. To by samo o sobě neprokazovalo, že se jednalo o uměle vytvořený srovnávací materiál; nicméně ostatní okolnosti tomu silně nasvědčovaly.

možnost zajistit ke zkoumání originál. 
Obr. 1: Sporné podpisy
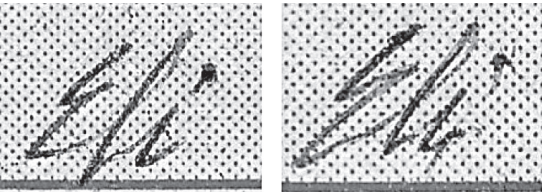

Zdroj: autor

Obr. 2: Srovnávací podpisy z nezpochybnitelného zdroje veřejné správy
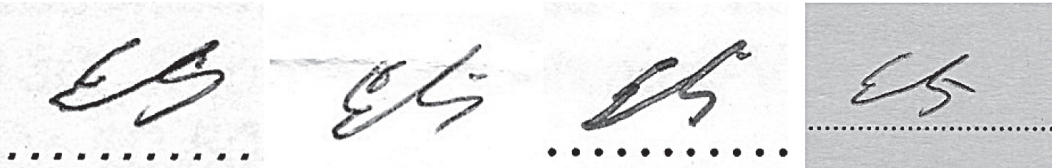

Zdroj: autor

Obr. 3: Uměle vytvořený srovnávací materiál
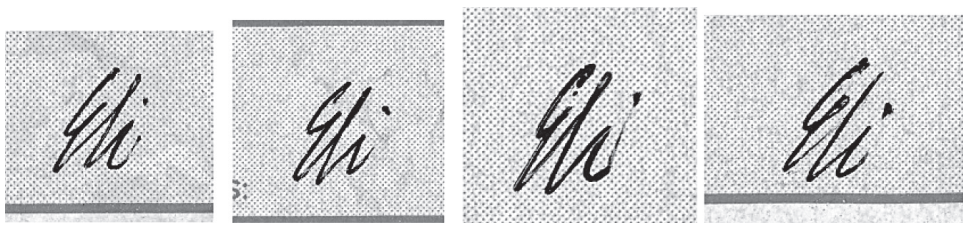

Zdroj: autor

Předmětné podpisy byly vyhotoveny na standardizované formuláře dodacích listů. Ty na první pohled vypadaly věrohodně; vykazovaly známky použití, byly rukopisně vyplněny a opatřeny razítkem dodavatele i podpisy dalších osob. Avšak zdroj, ze kterého měly tyto srovnávací materiály pocházet, rozhodně nebylo možno považovat za věrohodný. V průvodním dopise, který byl s předmětnými materiály zaslán právním zástupcem žalované, bylo uvedeno, že tyto dodací listy měla žalovaná najít na dvoře již zhruba deset let nefungující společnosti, u které zemřelý pisatel v minulosti pracoval.

Při bližším prohlédnutí dodacích listů bylo zjištěno, že při jejich seřazení podle uvedené datace neodpovídá střídání nánosu a vyblednutí razítkovací barvy v otisku firemního razítka. Dodací listy byly rukopisně vyplněny hůlkovým písmem a číslicemi; teoreticky by se mělo jednat o písmo zemřelého jako předávajícího, avšak byl to rukopis jiné osoby. Dalším faktorem svědčícím pro uměle vytvořený srovnávací materiál byly zjištěné shody v technice psaní písmene „"', zejména pak v charakteru spodního obratu (obr. č. 4). Stejná technika psaní se vyskytovala u sporných podpisů, inkriminovaných srovnávacích podpisů předložených žalovanou, ale i ostatních podpisů na dodacích listech, které měly znít na jména různých přebírajících osob. 
Obr. 4: podpis přebírajícího a předávajícího z jednoho uměle vytvořeného dodacího listu

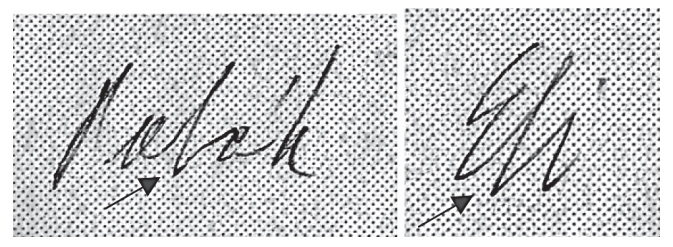

Zdroj: autor

Písmoznalec pracuje s hypotézami vzniku sporných podpisů, avšak zapotřebí je pracovat i s hypotézami vzniku srovnávacích podpisů - zvláště, když vznikají pochybnosti o jejich původu, který nelze považovat za věrohodný. $V$ tomto konkrétním prípadě vše nasvědčovalo tomu, že srovnávací podpisy předložené žalovanou byly uměle vytvořeny pro účely probíhajícího soudního řízení, resp. zadaného znaleckého zkoumání. Prokázání účelového předložení uměle vytvořeného srovnávacího materiálu, jehož cílem je svést znalce ke „špatnému“ výsledku zkoumání, je mnohdy těžko prokazatelné. Nicméně, to není úkolem znalce.

Pokud má však písmoznalec byt' jen pochybnosti o spolehlivosti zdroje a pravosti předkládaného srovnávacího materiálu (př́p. jeho části), tak ho ze zkoumání vyřazuje. Nastávají i situace, ve kterých má znalec pochybnosti o věrohodnosti srovnávacího materiálu, ale nemá dostatek objektivních důvodů k jeho vyloučení ze zkoumání. $\checkmark$ takovém případě může být stanoven tzv. podmíněný závěr, což znamená, že výsledek zkoumání je podmíněn „pravostí“ použitého srovnávacího materiálu.

A právě podmínka, že se teprve v prípadě prokázání autentičnosti (tj. pravosti) srovnávacího materiálu bude moci konstatovat, že je závět pravá, sehrála roli v další zajímavé kauze. Nepravost závěti údajné zůstavitelky Ludmily K. byla prokázána až "napodruhé". Bylo to způsobeno výchozími podmínkami, které nebyly pro prvotní zkoumání ideální - chyběla součinnost zadavatele a naopak přebýval uměle vytvořený srovnávací materiál.

Zadavatelem zkoumání byl magistrát, který měl přistup do pozůstalé nemovitosti zůstavitelky Ludmily K., ze které zajistil srovnávací písemnosti. Srovnávacího materiálu bylo sice velké množství, avšak bylo zjištěno, že obsahuje rukopisy více různých osob. Situace byla komplikovaná i tím, že z tohoto zdroje nebyly k dispozici žádné srovnávací podpisy a že většina materiálů nebyla datována a sestávala z rozsahem kratších poznámek. U mnohých ukázek byl sice předpoklad, že se jedná o písmo zůstavitelky, ale nebyla možnost tuto domněnku potvrdit. Rovněž nebylo možno vyhodnotit vývoj rukopisu po kvalitativní stránce v úplnosti, protože u většiny písemností nebylo zřejmé, kdy vznikly. Magistrát byl žádán o součinnosti při zajištění autentického srovnávacího materiálu, který by pocházel z neutrálního a nezpochybnitelného zdroje veřejné správy, ale tento materiál v první fázi zkoumání nepředložil. Vedle toho část srovnávacích materiálů tvořil životopis a popsané fotografie předložené dědičkou uvedenou v závěti. Výhodou bylo, že písemnosti se jmenovitě vztahovaly k zůstavitelce, odpovídaly sporné závěti druhem písma, formou i rozsahem a že obsahovaly ukázky podpisů. Avšak zdroj nebylo možno považovat za neutrální a nezpochybnitelný. 
Ručně psané texty i textový podpis na sporné závěti napsala v celém rozsahu jedna osoba, a to stejná, jejíž srovnávací materiály byly jako písmo a podpisy Ludmily K. předloženy dědičkou uvedenou v závěti. Ručně psaný životopis nebyl datovaný, ale $z$ jeho obsahu vyplývalo, že musel být sepsán 18 až 27 let před datací sporné závěti. $V$ době datace závěti bylo zůstavitelce 80 let, což by znamenalo, že v době vyhotovení životopisu jí muselo být v rozmezí 53 až 62 let. O to víc bylo nevěrohodné (i s ohledem na věk zůstavitelky v době údajného sepsání závěti), že písmo na závěti a životopisu bylo vyhotoveno jistě, plynule a mělo $v$ celém rozsahu naprosto jednotnou a stárím pisatele nepozměněnou kvalitu písma (obr. č. 5 a 6). S přihlédnutím ke zdroji, ze kterého životopis pocházel, vznikaly důvodné pochybnosti, že se jedná o uměle vytvořený srovnávací materiál. Závěr zkoumání bylo tedy nutno podmínit.

Obr. 5: Texty ze sporné závěti ( $v$ době vyhotovení mělo být pisatelce 80 let)

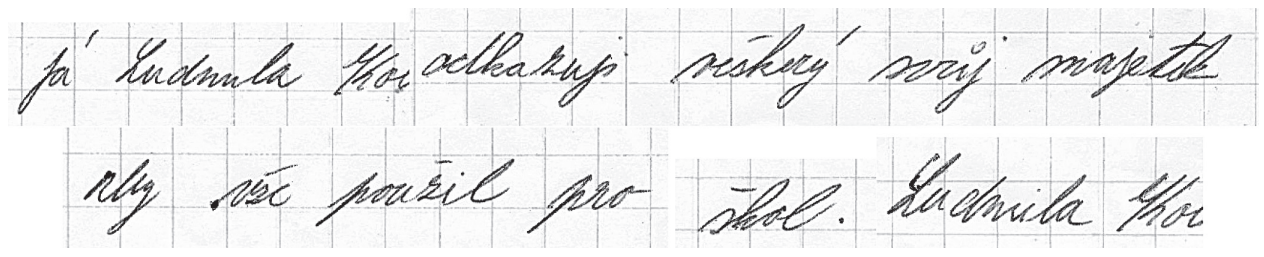

Zdroj: autor

Obr. 6: Texty z uměle vytvořeného životopisu ( $v$ době vyhotovení mělo být pisatelce 53 až 62 let)

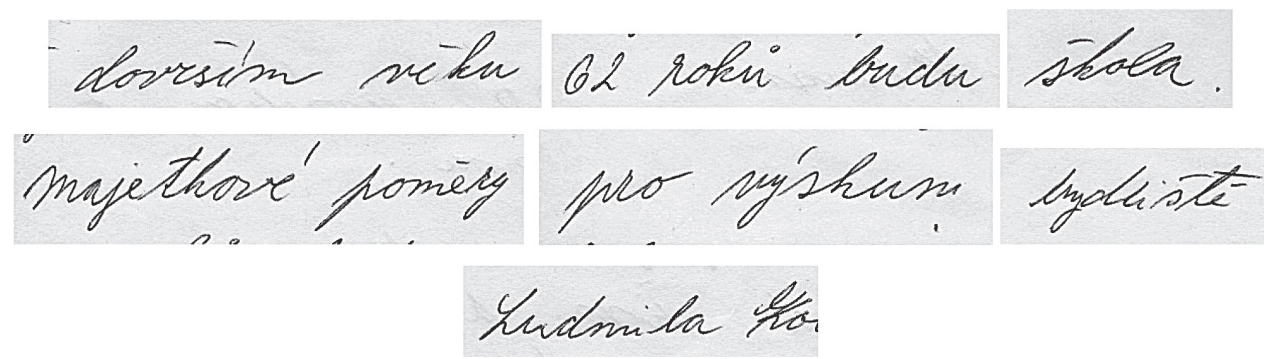

Zdroj: autor

K ověření autentičnosti materiálu bylo zapotřebí předložit časově adekvátní srovnávací materiály, u kterých by bylo nezpochybnitelné, že se jedná o písmo a podpisy zůstavitelky. To se s odstupem času magistrátu podařilo a ke zkoumání byly zajištěny ukázky vlastnoručních podpisů zůstavitelky, které se nacházely na osobních dokladech, o jejich autentičnosti nebylo pochyb. Na základě těchto nesporně pravých podpisů Ludmily K. bylo prokázáno, že sporný podpis na závěti a podpisy na srovnávacím životopisu nejsou pravé podpisy. Ručně psané texty i podpisy na sporné závěti a srovnávacích materiálech, které jako písmo a podpisy zůstavitelky předložila dědička uvedená v závěti, napsala a podepsala v celém rozsahu jedna osoba, nikoliv však uvedená zůstavitelka Ludmila K. S ohledem na zdroj a motivaci lze konstatovat, že se jednalo o uměle vytvořený srovnávací materiál, který byl potenciální dědičkou předložen úmyslně, aby znalec kladně potvrdil pravost padělané závěti. 
Uměle vytvořený srovnávací materiál, ukázky podpisů a písma zajištěné soudem z nezpochybnitelného zdroje veřejné správy a neodpovídající kvalita vyhotovení byly - obdobně jako $v$ předchozím př́padě - primárními faktory při zkoumání a prokázání nepravosti jiné závěti. Tu měl napsat a podepsat zůstavitel jen pár dní před svou smrtí, ve věku nedožitých 92 let.

Výpovědi žalobce i žalované se shodovaly $v$ tom, že zůstavitel $v$ posledních deseti letech nevedl osobní korespondenci, téměř nevycházel ze svého domu a potýkal se se zdravotními problémy, ale nikdy nebyl hospitalizován. Možnosti k zajištění srovnávacího materiálu byly omezené, přesto se nakonec podařilo zajistit písmo a podpisy zůstavitele ze dvou zdrojů. Rozsáhlejší část srovnávacího materiálu byla předložena žalobcem, který žil se zůstavitelem v jedné domácnosti a u soudu uplatňoval určení dědiců ze závěti. Žalovaná strana nedisponovala dokumenty s rukopisem či podpisy údajného zůstavitele, na což žalobce zřejmě spoléhal. Patrně již nepočítal s tím, že soud ke zkoumání zajistí spolehlivý materiál s písmem a podpisy zůstavitele, o jejichž autentičnosti a pravosti nemůže být pochyb. Jednalo se o úřední žádosti o vydání osobních dokladů z evidence obyvatel.

Písemný materiál od žalobce byl rozsáhlý, adekvátní sporné závěti použitým druhem písma i po časové stránce. Obsahoval dokumenty jako smlouvy a předávací protokoly s identifikačními údaji o zůstaviteli, další verze ručně psaných i strojově vyhotovených závětí, ručně psané poznámky i osobní vzkazy psané rodinnému přiteli. ${ }^{4} \mathrm{Na}$ první pohled působily dokumenty vcelku věrohodně, na druhý pohled již nikoliv. Nejenže materiál předložený žalobcem nápadně splňoval požadavky znalce kladené ve výzvě o poskytnutí součinnosti, ale také se diametrálně lišil od autentického srovnávacího materiálu. $\mathrm{K}$ nevěrohodnosti materiálu od žalobce přispívala i skutečnost, že srovnávací rukopis vykazoval neměnnou rychlost, kvalitu, sklon i velikost písma, ačkoliv měl pocházet ze širšího časového období. Na některých stvrzenkách, vyúčtováních a protokolech se nacházely v místě podpisu údajného zůstavitele i parafy jiné osoby, přitom nebyl důvod, aby tyto dokumenty podepisovaly dvě různé osoby (obr. č. 7).

Obr. 7: Parafa neznámé osoby a napodobenina podpisu zůstavitele na srovnávací stvrzence

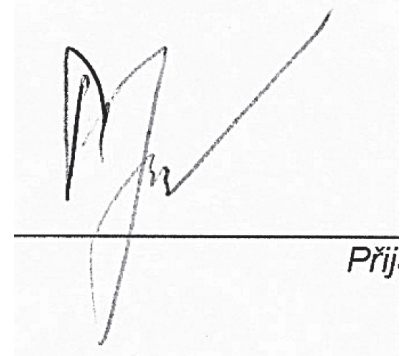

Zdroj: autor

4 Nutno podotknout, že další verze závětí, které byly predloženy jako srovnávací materiály, by ani obecně nebylo možno ke srovnání použít, nebot'se jednalo o dokumenty s prímou vazbou na spornou závět'. 
Obr. 8: Texty ze sporné závěti, které měl napsat údajný zůstavitel ve věku nedožitých 92 let
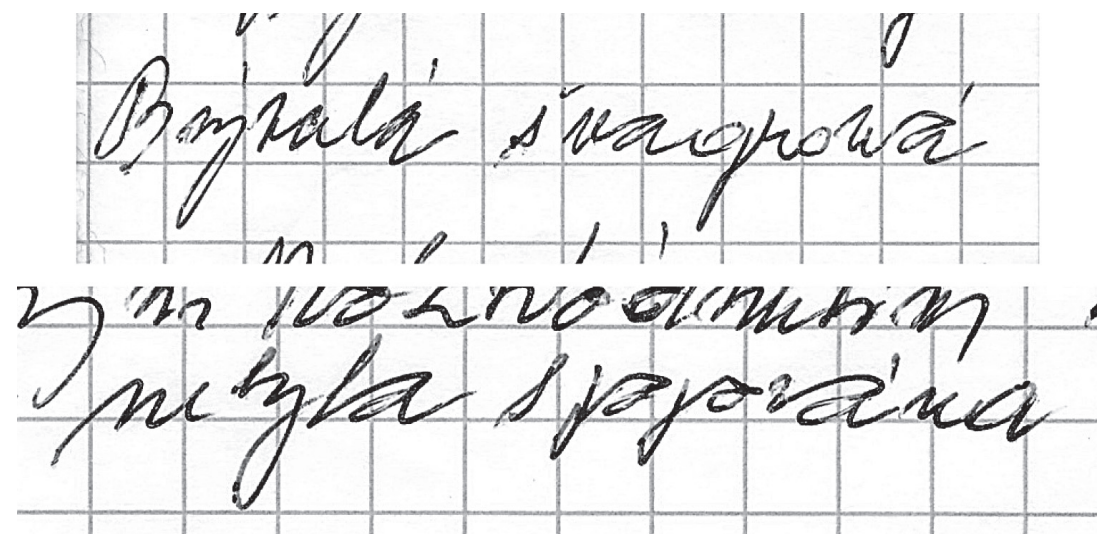

Zdroj: autor

Autentický rukopis a podpisy zůstavitele byly ovlivněny stařeckým tremorem, a to po dobu nejméně posledních 12 let jeho života. To s ohledem na věk pisatele nebylo nic neobvyklého. Neobvyklá a nevěrohodná byla kvalita a rychlost vyhotovení textů sporné závěti (obr. č. 8). Ta postrádala znaky typické pro rukopisy starších osob (obr. č. 9). Písmoznalecké zkoumání prokázalo, že srovnávací materiál předložený žalobcem sestával z napodobenin podpisů zůstavitele a v prípadě ukázek písma ze spontánního rukopisu neznámé osoby - téže osoby, která napsala vlastní obsah závěti. Nejen identifikačně hodnotné rozdíly, ale i samotná absence stařeckého tremoru vylučovaly, že by závět mohl sepsat a podepsat zůstavitel vlastní rukou. Tremor v písmu se projevuje u každého pisatele individuálně, v různé míre i podobě, např. od drobných lokálních třesů, přes neplynulé a křečovité psací tahy až po lomené obraty v oválech, obloucích a kličkách. Zhoršené motorické schopnosti pisatele a s tím spojený tremor však mohou vést až $\mathrm{k}$ tzv. rozpadu písma, tedy ztrátě schopnosti psát či se podepsat. Intenzita tremoru může být kolísavá (např. dle momentálního zdravotního stavu pisatele), nicméně u starších osob není reálný předpoklad, aby se se zvyšujícím věkem stařecký tremor z písma zcela vytratil a rychlost psaní a kvalita psacích tahů výrazně zvýšila. Tendence bývá obvykle přesně opačná, což také v tomto konkrétním případě prokázal autentický srovnávací materiál zajištěný soudem. 
Obr. 9: Ilustrativní ukázky stařeckého tremoru pisatelů starších 80 let

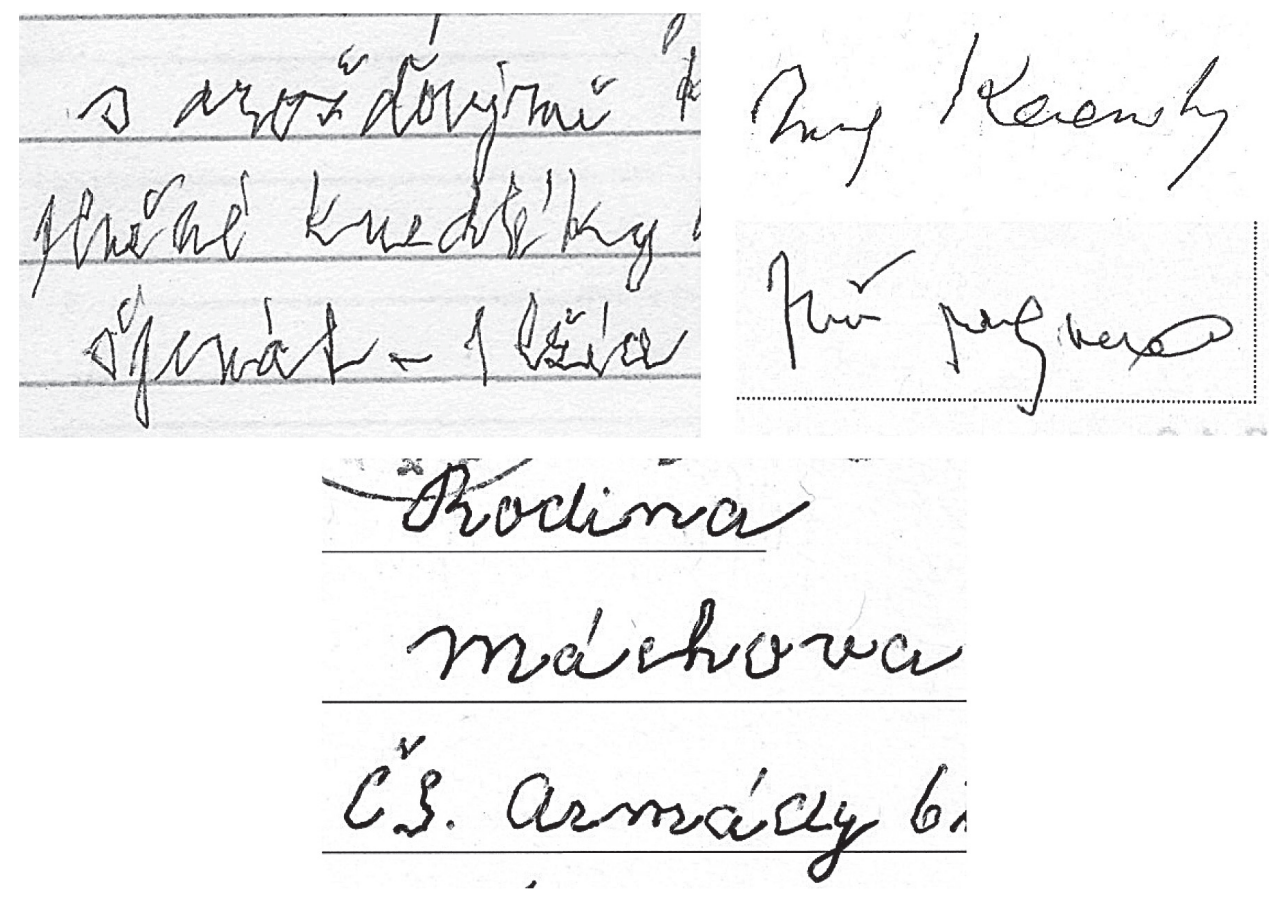

Zdroj: autor

Srovnávací materiál a padělaná závět' - obojí předkládané žalobcem - byly napsány jménem zůstavitele, obsahovaly osobní údaje a měly se tvárit jako věrohodné dokumenty vyhotovené za jeho života. Samotný charakter listin prokazoval, že se ze strany žalobce nemohlo jednat o neúmysInou kontaminaci, ale záměrné předložení uměle vytvořeného srovnávacího materiálu.

Součinnost soudu při zajištování neutrálního srovnávacího materiálu, a tím vytváření optimálních podmínek pro zkoumání jsou pro písmoznalce nezbytné. Jistě si sami domyslíte, jaké dalekosáhlé důsledky a poškození žalované strany by nastaly v př́padě, kdyby soud nezajistil úřední žádosti zůstavitele a při ověřování pravosti závěti by se vycházelo pouze z listin od žalobce.

Z doposud prezentovaných kauz by se mohlo jevit, že podvržený materiál se týká jen ověřování pravosti podpisu či písma nežijící osoby, což však vyvrací následující případ. V občanskoprávním řízení žalovaný tvrdil, že sporný podpis znějící na jeho jméno není pravý, nebot' neodpovídá vzoru jeho podpisu. $V$ době datování sporné smlouvy měl žalovaný úraz pravé ruky a podle jeho vyjádření nebyl schopen se $v$ daném období podepsat. Za účelem prokázání své verze předložil více než 20 dokumentů s vlastnoručními podpisy, které byly precizně seřazeny podle datace. Sporný podpis byl nacvičeného charakteru s graficky náročnou stavbou, zatímco předložené ukázky od žalovaného byly graficky nenáročné, v čitelném znění iniciál „JH“. 
Podpisový materiál, který pro účely zkoumání zajistil soud z různých neutrálních zdrojů, tvrzení žalovaného vyvracel. Jednak byly zastoupeny nezpochybnitelně pravé podpisy z období datace sporného dokumentu, které prokazovaly, že žalovaný byl v dané době schopen se podepsat, jednak podpisový materiál podléhal vysoké variabilitě, která se týkala i používání různých druhů podpisů. V souboru byly zastoupeny podpisy nacvičeného charakteru, textové podpisy ve znění celého jména i zjednodušené podpisy ve znění iniciál. O to více bylo zarážející a na první pohled nevěrohodné, že žalovaným předložený materiál, který sestával z 22 ukázek vlastnoručních podpisů, tvoří velmi jednotnou skupinu. Nepřirozeně stabilní ukázky podpisů, které měly podle charakteru předložených listin vznikat za odlišných okolností a v časovém rozmezí 4 let, byly v rozporu s poznanými podpisovými zvyklostmi pisatele. Současně potlačovaly hypotézu, že by se mohlo jednat pouze o selekci.

Skutečnost, že se jedná o uměle vytvořený materiál, prokázaly protlaky psacích tahů. Mikroskopickým prozkoumáním srovnávacích listin bylo totiž zjištěno, že protlačené psací tahy jednotlivých podpisů se vždy nachází v odpovídajícím umístění na následujícím předloženém dokumentu. $V$ infračerveném světle viditelné protlačené tahy plně odpovídaly grafickému tvaru podpisu, který byl na předchozí listině (Obr. č. 10). V prípadě, že dva po sobě seřazené dokumenty měly stejně umístěnou podpisovou doložku, tak byly na druhém dokumentu vedle viditelných tahů podpisu také zřetelné protlaky tahů dříve vyhotoveného podpisu. Způsob zápisu jednotlivých podpisů tedy prokazoval, že jednotlivé písemnosti musely sloužit jako psací podložka při podepisování předchozí listiny. Podle sdělení žalovaného, ale i uvedené datace měly srovnávací materiály vznikat v časovém rozmezí 4 let. Materiály byly ke zkoumání předloženy časově seřazené. U srovnávacích listin tak vznikala paradoxní situace, že protlak podpisu se nacházel na teprve v budoucnu „Vzniklé" smlouvě, protokolu či potvrzení.

Obr. 10: V pozadí viditelné protlaky psacích tahů z jiných podpisů

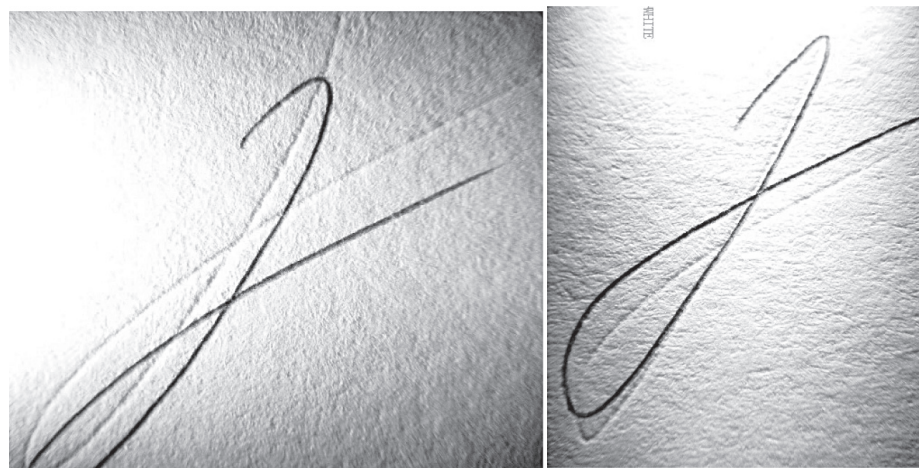

Zdroj: autor

U soudního jednání vyplynulo, že prefabrikovaný materiál měl svůj účel. Množství předkládaných ukázek mělo znalce i soud přesvědčit jednak o součinnosti žalovaného, jednak o tom, že vzor jeho pravých podpisů, tedy uměle vytvořených podpisů, neodpovídá tomu spornému. Nutno podotknout, že tyto podpisy nebyly druhem ani stavbou adekvátní spornému podpisu a pro účely zkoumání byly nevyužitelné. Žalovaný si svým jednáním 
pouze přitížil. Pravost sporného podpisu byla prokázána na základě soudem zajištěného materiálu.

Z prezentovaných případů je zřejmé, jak je průběh písmoznaleckého zkoumání a jeho výsledek ovlivněn srovnávacím materiálem. Účastníci řizení a jejich právní zástupci vstupují do soudních řízení s přesvědčením, že pokud zpochybní srovnávací materiál, znevěrohodní celý znalecký posudek. Snaha ovlivnit výsledek zkoumání stanovený na základě znalcem použitého srovnávacího materiálu, v horším prípadě úmysIně kontaminovat materiál, je proto stále aktuálnější. Z vlastní zkušenosti mohu uvést, že při předvolání k soudnímu líčení se často víc - než ke stanovenému závěru a průběhu zkoumání - vyjadřuji k použitému srovnávacímu materiálu. Aspekt dokazování znaleckým posudkem se stáčí do úplně jiné roviny a vzniká tak paradoxní situace, ve které znalec neobhajuje stanovený závěr, ale prokazuje pred soudem věrohodnost použitého srovnávacího materiálu. Dokonce ani zajištění autentického srovnávacího materiálu z neutrálního zdroje není zárukou, že nebude některým z účastníků řizení zpochybňován.

Bohužel se v praxi často setkávám se situací, že znalecké kompetence k zodpovězení otázky věrohodnosti použitého srovnávacího materiálu si přivlastňují samotní účastníci řízení, resp. jejich právní zástupci, přičemž soudy je při tomto jednání nechávají. Je však nutno si uvědomit, že nikoliv soud, nikoliv účastník řízení či jeho právní zástupce, ale pouze znalec z př́slušného oboru je schopen předložený srovnávací materiál kvalifikovaně vyhodnotit a př́padně se vyjádřit k pochybnostem o jeho autentičnosti a věrohodnosti. S otázkou, zda se v případě předložení uměle vytvořeného srovnávacího materiálu jedná o úmysIné a záměrné jednání, se musí vypořádat soud. Avšak na otázku, zda Ize předložený srovnávací materiál využít jako spolehlivý podklad ke zkoumání, může kvalifikovaně odpovědět pouze znalec.

Za autentičnost a spolehlivost srovnávacího materiálu sice nese zodpovědnost ten, kdo jej znalci předkládá ke zkoumání, nicméně je to znalec, který formou znaleckého posudku podává důkaz. Povinností znalce je vykonávat znaleckou činnost raádně a uvést všechny okolnosti, které mají význam pro rozhodnutí. Aby mohl písmoznalec svoji činnost vykonat raádně a podat správný znalecký posudek, neměl by o spolehlivosti a věrohodnosti použitého srovnávacího materiálu mít pochybnosti.

At už se jedná o zpochybňování autentičnosti použitého srovnávacího materiálu, účelovou i neúmyslnou selekci anebo kontaminaci materiálů, v některých př́padech dovršenou podvržením uměle vytvořeného srovnávacího matriálu, jedná se o negativní faktory ovlivňující znaleckou činnost v oboru písmoznalectví. Nezřídka má takové jednání za cíl zmařit průběh a výsledek písmoznaleckého zkoumání. Dané problematice Ize do jisté míry předcházet součinností soudů při zajištování srovnávacích materiálů z neutrálních a nezpochybnitelných zdrojů, čímž vytvoří znalci optimální podmínky pro písmoznalecké zkoumání. Tyto negativní jevy není reálné z praxe vymýtit, a proto musí být znalci při vyhodnocování srovnávacího materiálu velmi obezřetní. 


\section{Právní hledisko}

Výsledky činnosti znalce z oboru písmoznalectví jsou nepochybně významným důkazním prostředkem v rámci soudních řízení. Vypovídací schopnost posudku a spolehlivost jeho závěru mohou být do určité míry ovlivněny okolnostmi, které jsou podrobněji rozebrány v předchozím textu článku.

Proces získání potřebných ukázek podpisů a písma je v souladu s příslušnými ustanoveními trestního raádu závislý na fázi trestního řízení. Ve stadiu prověřování, tedy do zahájení trestního stíhání, lze vyzvat osobu k vydání věci, popř́padě tuto věc odejmout, na základě ustanovení § 158 odst. 3 písm. h) trestního řádu, který odkazuje na $§ 78$ a následující trestního řádu, přičemž podezřelého ani jinou osobu nelze ke splnění této povinnosti donutit hrozbou pořádkové pokuty.

V další fázi trestního řízení, vyšetřování, již je možné jiné osoby donutit hrozbou užití pořádkové pokuty, nicméně obviněného nikoliv. Takový postup orgánů činných v trestním řízení by byl v rozporu se zásadou nemo tenetur, tedy potažmo presumpcí neviny.

Písemnosti, které mají sloužit jako důkazní prostředek, podléhají režimu dle § 78 a § 79 trestního řádu. V trestním řízení je běžné, že ukázky písma se získají bud' prostřednictvím uplatnění institutu vydání věci ve smyslu ustanovení $§ 78$ trestního řádu, či odnětí věci dle $\S 79$ trestního řádu. Takový postup je príznivý z pohledu písmoznalce, nebot' pokud se podklady ke zkoumání získají v rámci domovních a jiných prohlídek prováděných podle trestního řádu - může se jednat např́klad o pracovní smlouvy, nájemní smlouvy, životopisy, diáře, dopisy, osobní deníky, zápisky v kalendáři, recepty, popisy fotografií - tak je jejich zdroj nepochybný a výrazně snižuje riziko kontaminace úmyslně padělaným materiálem.

Pokud jde o dikci § 78 odst. 1 trestního řádu, ten stanoví následující: „Kdo má u sebe věc, která může sloužit pro důkazní účely, je povinen ji na vyzvání předložit soudu, státnímu zástupci nebo policejnímu orgánu; je-li ji nutno pro účely náležitého zjištění skutečností důležitých pro trestní rízení zajistit, je povinen takovou věc na vyzvání těmto orgánům vydat. Při vyzvání je třeba ho upozornit na to, že nevyhoví-li výzvě, může mu být věc odňata, jakož i na jiné následky nevyhovění (\$ 66). Vyzvat k předložení nebo vydání věci je oprávněn předseda senátu, v prípravném řízení státní zástupce nebo policejní orgán."

Přičemž jiným následkem nevyhovění dle $\S 66$ trestního řádu se rozumí hrozba pořádkové pokuty. Ustanovení $\S 66$ trestního řádu uvádí: „... . kdo bez dostatečné omluvy neuposlechne př́kazu nebo nevyhoví výzvě, které mu byly dány podle tohoto zákona, může být předsedou senátu a v prípravném rízení státním zástupcem nebo policejním orgánem potrestán poř́dkovou pokutou do 50000 Kč."

Ustanovení § 79 trestního řádu uvádí: „Nebyla-li věc, která může sloužit pro důkazní účely, na vyzvání předložena nebo vydána tím, kdo ji má u sebe, může mu být na př́kaz předsedy senátu a v prípravném rízení na príkaz státního zástupce nebo policejního orgánu odňata. Policejní orgán potřebuje k vydání takového př́kazu předchozí souhlas státního zástupce; bez predchozího souhlasu může být přikaz policejním orgánem vydán jen tehdy, jestliže nelze předchozího souhlasu dosáhnout a věc nesnese odkladu." 
Tzv. ediční povinnost, tedy povinnost vydání věci, a hrozba jejího odnětí se vztahuje jak na podezřelého, resp. obviněného, tak na jiné osoby, které mohou mít takovou listinu u sebe.

Z naší ustálené judikatury a judikatury ESLP však plyne, že hrozbou pořádkové pokuty nelze $\mathrm{k}$ vydání věci donutit obviněného, nebot takové jednání by bylo $v$ rozporu $s$ již zmiňovanou zásadou zákazu donucení k sebeobviňování (nemo tenetur se ipsum accusare), která je chápána jako součást širšího principu presumpce neviny ve smyslu § 2 odst. 2 trestního řádu, a je zaručena čl. 37 odst. 1 a čl. 40 odst. 2, 3 a 4 Listiny základních práv a svobod.

V souladu s tímto názorem můžeme uvést též nález Ústavního soudu ze dne 20. 2. 2001, sp. zn. PI. ÚS 29/2000: „Donucování ke splnění povinnosti věc předložit cestou aplikace § 66 tr. ř. by bylo ústavní, jestliže by se týkalo jiné osoby než obviněného, zavázané povinností věc doličnou předložit."

Odnětí věci je zajištovací institut jiného, tedy závažnějšího charakteru. Pokud osoba, která má ediční povinnost, ji dobrovolně nesplní, bude jí věc odňata v souladu s ustanovením $\S 79$ trestního řádu, jak bylo výše uvedeno.

Jak vyplývá ze znalecké praxe, ukázky podpisů a písma, které předloží sám obviněný, nelze bezvýhradně přijímat jako spolehlivý srovnávací materiál. Dále pak platí, že nemožnost nutit obviněného $\mathrm{k}$ předložení těchto materiálů není možné vnímat jako překážku. To proto, že orgány činné v trestním řízení jsou povinny jednat v souladu se zásadou oficiality § 2 odst. 4 trestního řádu, kdy ukázky písma Ize obstarávat též z jiných, ideálně pokud je to možné, oficiálních zdrojů (např. úřední listiny, jako jsou žádosti o vydání občanského či řidičského průkazu). Ty jsou pak pro znalecké zkoumání objektivnější. A jak vyplývá z príspěvku znalkyně, obdobnou zásadou se řídí i sami znalci.

I písmoznalecký posudek je třeba soudem hodnotit, protože se jedná o důkaz. Právě k rozsahu hodnocení znaleckého posudku soudem se vyjadřuje nález Ústavního soudu ČR, sp. zn. III. ÚS 299/06: „Hodnotit je třeba celý proces utváření znaleckého důkazu, včetně prípravy znaleckého zkoumání, opatřovánípodkladů pro znalce, průběh znaleckého zkoumání, věrohodnost teoretických východisek, jimiž znalec odůvodňuje své závěry, spolehlivost metod použitých znalcem a způsob vyvozování závěrů znalce." Z uvedeného vyplývá, že hodnocení přípravy a opatřování podkladů pro znalce může být velmi důležité. V prípadě, že povinný subjekt předloží znalci ke zkoumání falešné či záměrně kontaminované matriály, je takové jednání motivováno snahou získat výhody a příznivé rozhodnutí orgánů činných v trestním řízení. Z kazuistiky uvedené písmoznalkyní je zřejmé, že obdobné jednání se četně promítá i do civilních soudních sporů.

Soud by $v$ takovém prípadě měl rízení přerušit a dát podnět orgánům činným v trestním řízení, aby se zabývaly podežrením ze spáchání trestné činnosti. Obdobně by měly postupovat i orgány činné v trestním řízení, pokud vyvstane podezření, že byly předloženy falešné důkazy. Znalec je osoba, která má v procesu dokazování na podkladě svých odborných znalostí ožrejmit určitou skutečnost důležitou pro objasnění věci, a výsledek její činnosti v tomto směru, což je znalecký posudek, je jedním z důkazních prostředků, 
jímž znalec dává odpověd' na specifikované odborné otázky a jehož závěr má zpravidla významný vliv na rozhodnutí orgánů činných v trestním řízení. Proto se lze domnívat, že i předložení falešných podkladů pro zpracování takového posudku bude mít charakter trestné činnosti.

Zahraniční právní úpravy takové jednání definují jako protiprávní. Též náš zákonodárce si je dobře vědom závažnosti jednání spočívajícího v ovlivňování rozhodnutí soudů padělanými či pozměněnými listinami či věcmi, resp. sváděním různých osob ke křivým výpovědím či znaleckým posudkům. Takový způsob nepřípustného ovlivňování soudního rozhodnutí proto označil zákonodárce nově za trestný v novele trestního zákoníku provedené zákonem č. 287/2018 Sb., s účinností od 1. 2. 2019. V ustanovení § 347a tr. zákoníku je jako trestný čin maření spravedlnosti postihováno právě uvedené jednání, které se podle trestního zákona z roku 1852 postihovalo jako jednání podvodné. ${ }^{5}$

Trestní zákoník ve zmiňovaném § 347a, maření spravedlnosti, uvádí:

"(1) Kdo pro účely zahájení rízení před soudem, před mezinárodním soudním orgánem nebo trestního řízení anebo v takovém řízení předloží věcný nebo listinný důkazní prostředek, který má podstatný význam pro rozhodnutí, o kterém ví, že je padělaný nebo pozměněný, $v$ úmyslu, aby byl použit jako pravý, anebo padělá nebo pozmění takový důkazní prostředek v úmyslu, aby byl použit jako pravý, bude potrestán odnětím svobody až na dvě léta."

"(2) Kdo sám nebo prostřednictvím jiného poskytne, nabídne nebo slíbí prospěch jinému nebo pro jiného za účelem spáchání trestného činu křivého obvinění (§ 345), křivé výpovědi a nepravdivého znaleckého posudku (§ 346) nebo křivého tlumočení (§ 347), bude potrestán odnětím svobody až na tři léta."

V této souvislosti je třeba zdůraznit, že padělaný či pozměněný věcný nebo listinný důkazní prostředek musí mít „podstatný význam pro rozhodnutí". Šámal v komentáři k trestnímu zákoníku ${ }^{6} \mathrm{k}$ trestnému činu dle ustanovení § 346 křivá výpověd' a nepravdivý znalecký posudek, k pojmu „podstatný význam pro rozhodnutí“ uvádí: „Zda jde o takovou okolnost, vždy nutno posuzovat ve vztahu ke konkrétnímu prípadu. Nemusí se však jednat o okolnost mající rozhodující význam. Zpravidla půjde o skutečnost, kterou orgán uvedený $v$ tomto ustanovení musí vzít v úvahu při řešení otázky, o níž má rozhodovat (v trestním rízení půjde o všechny okolnosti, které mohou ovlivnit rozhodnutí o vině nebo trestu, o uložení ochranného opatření nebo o nároku poškozeného)."

S ohledem na dosavadní nedostatek judikatury u tohoto zákonného ustanovení či výkladu v prestižních komentárích $\mathrm{k}$ této nové právní úpravě bude patrně vhodné v souvislosti s ustanovením § 12 odst. 2 trestního zákoníku ve výkladu tohoto zákonného ustanovení postupovat následovně. Pod pojem „podstatný význam pro rozhodnutí" by se mělo subsumovat takové jednání, kdy bude předložena orgánu činnému v trestním řízení listina, a Ize se domnívat, že půjde i o případy, kdy takové jednání bude směřovat proti znalci, o kterou se následně podstatným, tedy zásadním způsobem opře výrok o vině či

5 Převzato a komentováno z Usnesení Nejvyššího soudu 5 Tdo 533/2018.

6 ŠÁMAL, Pavel. Trestní zákoník: komentář. Praha: C. H. Beck, 2010. Velké komentáře. S. 2958 a násl. ISBN 978-80-7400-109-3. 
nevině osoby, proti které se vede toto trestní rízení. Prakticky to tedy znamená, že tato listina skutečně zásadním způsobem ovlivnila zjištění skutkového stavu věci, o kterém nejsou důvodné pochybnosti ( $\$ 2$ odst. 5 trestního rádu, věta první). Přičemž by tato listina bud'to sama, nebo v souvislosti s dalšími důkazy zásadním způsobem ovlivnila rozhodnutí orgánu činného v trestním řízení.

Tato změna vyvolala mezi odbornou veřejností obrovské diskuze, zejména pokud jde o činnost advokáta při poskytování právní služby klientům. Česká advokátní komora se k této problematice několikrát vyjadřovala. Z informace představenstva ČAK, která byla naposledy otištěna v Bulletinu advokacie č. 6/2019 a doplněna v č. 11/2019, vyplývá, že: „Pokud jde o jednání, které činí advokát (byt jako zástupce klienta na základě plné moci v rámci přímého zastoupení) v rámci příslušného procesního úkonu jakožto zástupce účastníka řízení, může být pachatelem i advokát, a to bez ohledu na to, kdo důkazní prostředek padělal nebo pozměnil (za podmínky, že advokát o této skutečnosti ví). Avšak pokud tak činí klient advokáta (např. jde-li o osobní úkon v rámci daného řízení), je pachatelem klient, a nikoli advokát." ${ }^{\text {"7 }}$

\section{Závěr}

Je tedy zřejmé, že ne každé předložení padělaného či pozměněného důkazního prostředku bude naplňovat skutkovou podstatu daného trestného činu. $\mathrm{K}$ tomu, aby toto jednání bylo trestné, bude se muset jednat o věcný nebo listinný důkazní prostředek, který bude mít současně tzv. „podstatný význam pro rozhodnutí“ a bude použit v zákonem předpokládaném úmyslu, jak bylo výše uvedeno.

\section{Použitá literatura}

Usnesení Nejvyššího soudu 5 Tdo 533/2018.

Nález Ústavního soudu ze dne 20. 2. 2001, sp. zn. PI. ÚS 29/2000.

Nález Ústavního soudu ČR, sp. zn. III. ÚS 299/06.

Bulletin advokacie. 2019, č. 11.

Zákon č. 40/2009 Sb., trestní zákoník.

Zákon č. 141/1961 Sb., trestní rád.

ŠÁMAL, Pavel. Trestní zákoník: komentár. Praha: C. H. Beck, 2010. Velké komentáře. ISBN 978-80-7400-109-3.

\footnotetext{
7 Bulletin advokacie. 2019, č. 11, str. 7.
} 